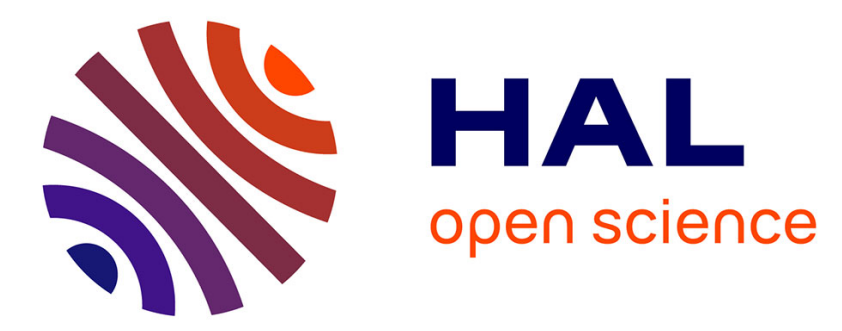

\title{
Analyzing student practice in language resource centres of the Louis Pasteur University in Strasbourg: is planning really central to self-directed learning? Peggy Candas
}

\section{- To cite this version:}

Peggy Candas. Analyzing student practice in language resource centres of the Louis Pasteur University in Strasbourg: is planning really central to self-directed learning?. Innovation in Language Learning and Teaching, 2011, 5 (2 (2011)), pp.191-204. 10.1080/17501229.2011.577534 . hal-00943543

\author{
HAL Id: hal-00943543 \\ https://hal.science/hal-00943543
}

Submitted on 7 Feb 2014

HAL is a multi-disciplinary open access archive for the deposit and dissemination of scientific research documents, whether they are published or not. The documents may come from teaching and research institutions in France or abroad, or from public or private research centers.
L'archive ouverte pluridisciplinaire HAL, est destinée au dépôt et à la diffusion de documents scientifiques de niveau recherche, publiés ou non, émanant des établissements d'enseignement et de recherche français ou étrangers, des laboratoires publics ou privés. 


\title{
Analyzing student practice in language resource centres of the Louis Pasteur University in Strasbourg : is planning really central to self- directed learning?
}

\author{
Peggy Candas
}

\section{Laboratoire Interuniversitaire des Sciences de l'Education et de la Communication (LISEC), University of Strasbourg, Strasbourg, France}

Email: peggy.candas@unistra.fr

(Received 1 February 2010; final version received 18 February 2011)

\begin{abstract}
The Language Resource Centres (LRCs) of the Louis Pasteur University ${ }^{1}$ (LPU) in Strasbourg were created to promote both language learning and the development of learner autonomy among university students. Teacher support in the LRCs is based on the prevailing principles found in the literature on self-directed learning. But little is in fact known about how learner autonomy actually develops and a few authors have started to challenge the assumption that planning is central to self-directed learning. Our doctoral research set out to comprehensively study how university students learning a foreign language in an LRC proceed when encouraged to self-direct learning. The corpus of data was obtained using a methodology combining direct observation of individual learners' work sessions and subsequent interviews. The confrontation of the data with literature on autonomy led us to identify four lines of analysis, according to which student activity was then qualitatively analyzed. This article will focus on one of them: if and how the learners controlled or monitored their learning process. Although our results remain to be confirmed on larger numbers of learners studied for a longer time span, they open challenging areas of investigation into the nature of the processes involved in selfdirected learning.
\end{abstract}

Keywords: learner autonomy; self-directed learning; planning; monitoring; language learning; activity; language resource centre; student; university

\section{Introduction}

In France as well as in Europe considerable energy has been devoted to discussing and promoting the development of autonomy in learners, young and old, in particular in the field of language teaching and learning (e.g. Little 1991; Albero 2003; Carré 2005; Dumazedier 2002). The authors of numerous books and articles (e.g. Carré 1992; Carré, Moisan, and Poisson 1997; Courtois and Prévost 1998; Foucher and Hrimech 2000; Carré and Moisan 2002) attempt to operationalize this notion so as to guide teachers and trainers in their daily practice. However, a close look at the existing literature reveals that what Little (1991) more precisely calls 'learner autonomy' is rather vaguely defined. Although it is not often explicitly stated in the 
French and European literature on learner autonomy, most of the practical advice given to educators to develop learner autonomy rests on research on self-directed learning (e.g. Knowles 1971; Tough 1971), a more pragmatic notion which was originally developed, under different names, by north-American research in the adult education field (cf. Tremblay and Eneau 2006, 76-79) and then imported into French and European research. As far as this very problematic terminological confusion is concerned, Holec's work stands as an exception, in that he clearly distinguished autonomy, defined as an ability, a power to do something, from self-direction in learning, which he described as an attitude, a way of doing something, thereby using the above-mentioned ability (personal translation, Holec 1981b, 21).Therefore, for this author, the word autonomous is a term which refers to a particular characteristic of the learner: an autonomous learner is a learner who knows how to learn. In no way can it be used to describe the way learning is conducted, contrary to self-direction in learning, which, he argues, leads to self-directed learning. When turning to NorthAmerican research on autonomy and self-directed learning, similar terminological difficulties can be found. According to Tremblay $(2003,59)$, the notion of selfdirected learning remains ambiguous, definitions being unstable and sometimes even contradictory. For Benson $(2001,34)$, further confusion around the terms autonomy and self-directed learning, and their distinction, arises from the fact that they are often used differently in the fields of adult education and language learning. As a necessary basis for our doctoral research, we chose to keep Benson's definitions as reference definitions as we found they had reached the widest consensus:

'Perhaps the most important distinction to be made in the field of language learning is between autonomy as an attribute of the learner and self-directed learning as a particular mode of learning in which the learner makes the important decisions about content, methods and evaluation. Autonomy can be considered as something that learners possess to various degrees. Self-directed learning can be considered as something that learners are able to do more or less effectively, according to the degree that they possess this capacity'. (Benson 2001, 34) 
Since the 1970s and the publication of numerous articles on the organisational dimension of adult self-directed learning, especially in north-American research, the idea that planning is central to self-directed language learning has prevailed:

\footnotetext{
'In previous research in self-directed learning, Tough (1971), Peters and Gordon (1974), Penland (1979), and Hiemstra (1975) have reported or implied the existence of detailed preplanning of self-directed learning by adults.

Specifically, Tough (1971, 116-117) identified thirteen steps in planning that the learner 'sometimes takes in a self-planned project'. These steps include: identifying in detail what is to be learned, resources and methods for learning, time devoted to the effort, where to learn, pace of learning, deadline for completion, etc. Tough suggests that these actions may take place so rapidly that the learner is not even aware of them but that they occur nonetheless.' (Spear and Mocker 1984, 2)
}

This widely accepted principle in the field is of course of the utmost importance for teachers and trainers and largely influences the way they try to foster the process of autonomy development in learners. Researchers therefore tried to determine the kind of institutional training which could be offered to learners who wanted to acquire or develop abilities to self-direct their projects (Benson 2001, 80-84). Research on learning strategies (Wenden 1983; Oxford 1990; O’Malley and Chamot 1990), which set out to identify types of attitudes and strategies used by efficient learners and train less efficient learners to use them, turned out to be a major source of inspiration.

The Language Resource Centres (LRC) of the Louis Pasteur University (LPU) in Strasbourg were created to promote both language learning and the development of learner autonomy among university students not majoring in languages. A detailed historical account of how these centres were designed after several years of work and experimentation by a team of researchers and teachers in both the fields of educational sciences and language learning can be found elsewhere (Poteaux 2000, 2003). However, it is important to note that the pedagogical principles implemented in those centres largely derive from the French and north-American research on selfdirected learning. Practically speaking, there are seven language resource centres (replacing traditional classrooms) where students come to learn languages with their 
teachers. A great number of resources, very diverse, are available for language learning and teachers are always present. Although not majoring in languages, the students have compulsory credits for at least one language. The development of learner autonomy while learning one or several languages is set as an explicit goal and teachers act both as language experts and counsellors (Gremmo 1995) who discuss needs, goals and learning trajectories with learners. Needless to say that the teachers also design and/or implement reflexive tools, such as the European Language Portfolio $^{2}$, for this purpose. Through frequent teacher-student interaction, students are encouraged to constantly reflect on their work, i.e. set learning objectives and choose adequate resources accordingly, define practical modalities and learning strategies, and self-evaluate their progress (Holec 1981a, 1997). They are also evaluated at the end of the semester on their capacity to discuss their learning programme critically, assess their progress and define general directions for the compulsory language module they will enroll in the following semester.

A preliminary study to our doctoral research (Candas 2005), conducted in the LPU centres, showed an important gap between teachers' intentions and student practice. Indeed, although teachers encouraged learners to define learning objectives, a programme and steps, the choices students made appeared to be linked to a large extent to other parameters like circumstances - or chance - or resources present in the environment. This finding seemed to challenge the assumption that planning is central to self-directed language learning, although the university context led us to remain very cautious. Following further inquiry in the adult education field, we found out that Danis and Tremblay $(1985,1987)$ were actually very critical of the otherwise largelyaccepted principles prevailing in the field of adult education practice and had 
conducted a critical review of prevailing adult learning principles (Danis and Tremblay 1985):

'Adult education practice tends to be influenced by the particular sets of principles
prevailing in the field (Fox 1981). These principles, in turn, reflect the underlying
explicit or implicit assumptions (Brundage and MacKeracher 1980) regarding how adults
learn and how they should be taught.
(...) a critical review of the prevailing principles may prove to be a most useful
prerequisite to their implementation, inasmuch as some of these assertions and
recommendations (Parsons and Johnson 1978; Pratt 1984; Zemke and Zemke 1981) may
be found to be either partly or completely erroneous.' (Danis and Tremblay 1987, 4)

As far as the organisational dimension of self-directed learning is concerned, and more precisely the issue of planning, Eneau (2000, 41-45), Benson $(2001,77-78)$ and Tremblay $(2003,150)$ all refer to what they consider to be an important study in the field, carried out by Spear and Mocker (1984):

'Spear and Mocker's findings are of interest because they call into question the assumption that autonomous learning is necessarily planned learning. ' (Benson 2001, 78)

All this led us to embark on a comprehensive research project on self-directed learning in an academic context, in the sense that we aimed, not at validating or invalidating pre-established hypotheses, but, on the contrary, at comprehending the observed phenomena and contributing to their description in order to suggest possible explanations or a model. In the frame of this article, it is not possible to adequately detail the whole of our doctoral research; therefore we will focus on the chosen design and methodology of the study and present the results for one line of analysis only.

\section{Design of the study}

The aim of our doctoral research was to comprehensively study how university students in the LPU language resource centres proceeded when asked to endorse responsibility so as to learn a language, encouraged and helped in this design by teachers. This obviously meant gathering data on individual learners' activity when learning. Vermersch (2003) showed that, when asked to explain in great detail how 
they proceeded for a particular task in their specialized field, the description that experts made of the sequence of actions they thought they performed did not coincide with what they really did in an effective situation. This led us to decide against collecting discourse material as the primary source of data and to prefer direct observation, on the basis that it would enable us to obtain detailed and situated descriptions of learners' activity in the language resource centres - activity being understood in a broad sense as choice, action, interaction, etc. However, preliminary tests made it quite clear that learners' activity could not be fully apprehended through direct observation only, since part of the activity was not visible. What is more, we subscribe to the definition of 'activity' given in Astolfi (2008), where it is described as three-fold and comprising the level of operation (the material dimension of activity, the how), the level of action (the cognitive dimension, the why, the aim), and the level of activity (the intentional dimension, the for what, the motive). This model is inspired from Leontiev (1975) and implies that what a person's actions mean to him/her is essential to fully comprehend a particular sequence of events. The chosen methodology for data collection therefore combined observation sessions of individual learners working in the language resource centres with directive interviews, immediately following observation sessions (the sessions were therefore still fresh in the learners' minds).

\section{Participants}

Teachers working in the Louis Pasteur University (LPU) language resource centres were informed by mail about the study. They were told that the researcher was looking for volunteers among first-year students who had enrolled for an English compulsory module and that the protocol included the observation of several working sessions in the LPU centre for each volunteer, as well as students' interviews. One 
male and three female teachers responded positively and accepted that the researcher come in one or several of their classes to try to recruit one volunteer in each of the classes. In their groups of students, five female and three male students accepted to participate, knowing four of their working sessions would be observed by the researcher and that there would be a twenty-minute interview with the researcher (and without his/her teacher) after each of the observed session. Each student was guaranteed that his/her name would not appear in the data and signed an informed consent. The aim of the study was presented in general terms to all participants: 'learning more about how students work in the language resource centres'.

First-year students in their second semester of study at university were targeted because it was hypothesized that this was a relevant period to observe learner autonomy developing, since students had recently left high school and entered university. Moreover, as it is deemed a crucial time for students in the process of familiarisation with the language resource centres, LPU language teachers are known to concentrate a lot of their efforts as counsellors on first-year students. Because the researcher is proficient in English, and not in the other languages offered in the centres (German, Spanish), and had to be able to understand precisely the observed student's actions and interactions (e.g. what he/she chose to do, how he/she was going about it, what he/she said to other students or the teacher, what he/she was told), participants had to study this particular language in the centres to be eligible for the study. No other criterion was imposed. If French is also taught in the centres, foreign students participating in study abroad and exchange programmes such as Erasmus programmes and studying French in the LRCs as part of their curriculum were voluntarily excluded from the study because they constitute a very special population inasmuch as they are immersed all day long in situations where the language they are 
trying to learn is spoken or used, contrary to most 'more traditional' students coming to the centres. The researcher made sure that the group of students volunteering went to different language resource centres and were majoring in diverse disciplines. The eight participants came to be included in the study quite randomly, although it must be said that, while most of them volunteered when the teacher asked the whole group of students in the class if someone accepted to participate in the study, some were among two or three students to which their English teacher asked directly if they wanted to participate.

\section{Data collection}

For each of the eight students included in the study, a series of four observation sessions was conducted. Each observation session lasted an hour and a half to two hours, depending on the student's timetable and on his/her wishes. Indeed, the official work sessions included in the students' timetable last two hours, but each student was free to interrupt the session or continue to work; however, the researcher asked $\mathrm{him} /$ her to stop working half an hour before leaving the centre so as to have enough time for the interview.

During the session, the researcher, carrying only a clipboard, sheets of paper, a pen and a highlighter, was sitting behind the observed student and slightly on his/her right or left, but at quite a short distance so as to be able to see precisely what actions the student was performing and what he/she was looking at, as well as hear what he/she was saying or was told. If the observed student went anywhere in the centre, the researcher followed after a few seconds, standing at a reasonable distance. The participant and the researcher did not talk or interact in any way, except at the beginning of the session when they greeted one another and also sometimes when the student felt he/she had justify an action, e.g. when doing something personal or going 
to sit somewhere else in the centre. The researcher had also informed the LRC teachers that she would prefer not being addressed during the observation sessions. Globally, the researcher's request was respected.

All this was negotiated with the observed students individually when the researcher met them for the first time: the researcher explained how she intended to proceed and why, insisting that she would try not to disturb the student's work, encouraged the student to give his/her opinion or impressions, discussed slight modifications which could be agreed upon, and tried to obtain explicit consent on the procedure. During the interviews following the observation sessions, the researcher regularly asked the student for feedback on how she conducted her observations, trying to make sure that the student still felt satisfied by the way in which the researcher was carrying out the established contract and was not judging her too intrusive.

During each observation session, detailed notes were taken by the researcher on the student's actions and interactions, without any grid in order not to limit observation to pre-established categories. Indeed, the aim was to study the activity of students in the LRCs in its most general sense, and not only in the restrictive meaning of intellectual work. The researcher therefore recorded as many actions as possible so as to obtain a written observation report as faithful to what she had seen as possible. Of course, recording every single action is utterly impossible and the researcher's gaze acts as a filter, undeniably. Moreover, the speed with which successive actions are undertaken can be amazing, as in the case of one of our participants when he surfed the internet. However, the researcher did her best to record all practical actions and interactions with other students and teachers, without neglecting more subtle activity such as pauses. To facilitate the subsequent interview, any action which might 
require an explanation was immediately highlighted by the researcher in her notes. On the same day as the observation session, the detailed observation report was typed by the researcher on her computer; the rough notes were nevertheless carefully kept. At the end of each observed session and after each time asking for the student's explicit consent, photocopies of the student worksheet and of all work documents used or produced by the student during that session were made. The researcher sometimes had to insist because the students felt some work documents such as drafts were not interesting enough (there were no cases where the students refused because they thought a document was too personal).

The subsequent interviews were done in French, which was either the mother tongue of the student or a language he/she mastered well enough to be adequately understood by the researcher. They were directive interviews, in which the researcher, using her notes, narrated almost everything she had seen the student doing in chronological order to him/her, asking very vague and open questions to obtain details without inducing a particular answer. People who are asked to talk about their activity performed in a singular situation at one given time easily wander away from particular actions and tend to discuss classes of events (i.e. what they generally do when they are in such a situation) rather situated events (i.e. what they did in this particular situation at that precise moment) (Vermersch 2003), so the researcher sometimes had to interrupt and redirect the interviewee when he/she strayed from situated actions. The interviews lasted twenty to forty minutes. With the student's consent, they were recorded on an audio tape and later fully transcribed.

At the end of the study, each participant accepted a final individual interview in French with the researcher, in which the learner's work during the two semesters spent in the LRC was discussed. They also filled in several questionnaires aiming to 
collect personal and biographical information. These enabled the researcher to gain more general knowledge about them.

\section{Data analysis}

Through empirical inquiry into the data after it had been transcribed, ideas found in the literature read by the researcher in diverse theoretical and research fields including biology, neurosciences, educational sciences were repeatedly confronted with the data available for each participant in the study. The researcher's aim was to try to identify common elements to the corpus of data and to literature, which might help to make some progress in our understanding of how learners proceed when self-directing language learning. This led to the identification of four main lines of analysis, a process we will detail for one of them.

We have already briefly mentioned the study led by Spear and Mocker (1984). Their preliminary findings show that adults who successfully self-directed a project to learn something did not necessarily plan their learning very precisely at the beginning of the project. On the contrary, in their data the authors found only rare instances of planning, which turned out to be also very vague. As the learning process nevertheless appeared deliberate and logical, they set out to identify the factors structuring selfdirected projects. Their final results showed that the participants in the study had not tried to find a great number and variety of resources so as to choose the best ones for their learning project, but had in fact used a very limited number of resources, sometimes even only one, readily available in their immediate environment or found by chance. They had always chosen one of the first ones that suited the project. Moreover, all that was necessary to the learning process - structure, method, resources, learning conditions - was most of the time given or dictated by circumstances. The learning process progressed, not in a linear way, but from one 
learning episode to another, and it was only retrospectively that it gave the impression of being linear and directed towards a long-term objective. The authors coined the term 'organizing circumstance' to define these opportunities which the adult learners had seized:

'(...) the researchers derived the concept of the Organizing Circumstance which postulates that self-directed learners, rather than preplanning their learning projects, tend to select a course from limited alternatives which occur fortuitously within their environment, and which structures their learning projects.' (4)

Spear and Mocker's study suggests that specific circumstances at a precise moment in the life of a learner play an essential role in structuring, organizing, one might even say limiting, the learning process - more than the learner's own will and ability to preplan and monitor it.

Danis and Tremblay $(1985,1987)$ reached similar conclusions. In this study, these researchers critically reviewed prevailing adult learning principles in the adult education field by comparing the learning principles suggested in the works of experts in this field (called 'the authors' in the quotations) with principles inferred from the analysis of the descriptions of their own learning experiences made by successful selftaught adult learners. Danis and Tremblay $(1985,438)$ cautiously remark, in their conclusion, that extrapolations from self-taught adult learners to adult learners in general should be validated, but the fact is that, as Benson reminds (2001, 76-77), part of the research on adult self-directed learning (e.g. Gibbons et al. 1980; Brookfield 1981) has long tried to identify recurrent traits or attitudes in self-taught adults, usually defined as learners who became experts in a domain for which they did not receive formal training. If Danis and Tremblay's study validated the principle according to which 'the learning process is activated and controlled by the learners themselves' (personal translation, Danis and Tremblay 1985, 427), the learning process did not seem to be composed of a succession of learning activities following 
one another in a sequential and unidirectional order, geared towards a precise goal, with carefully predetermined steps. Therefore, the results contradict the assumption that linear preplanning is central to self-directed learning. Yet, it was unclear what kind of control or monitoring the learners exerted:

\begin{abstract}
'Based on a linear, cyclical interpretation of the adult learning process (...) the authors mostly interpret the learners' activities in terms of management (...). Self-taught adults do not describe their own learning processes from a managerial point of view; they do not seem to follow linear, predetermined steps related to the planning and evaluation of their learning activities. Yet, they seem to exert control over their whole learning endeavor: Throughout their learning process, self-taught adults assume the monitoring of their own learning, even when consulting external agents or when participating in formal educational activities. Little is known to date about the type of monitoring which is involved here.' (Danis and Tremblay 1987, 6)
\end{abstract}

The study does give some insights into what actually structured the learning process of these learners:

'(...) the heuristic learning process seems to prevail: Self-taught adults proceed in a heuristic manner, within a learning approach which they organise around intentions, redefine and specify without following any predetermined patterns. In this context, the impact of random events upon the entire learning process also stands out: Self-taught adults, in order to learn, take advantage of any opportunities that random events may offer them.' (6)

In other words, the self-taught adults described their learning process in terms of very large and flexible goals, which they rarely chose at the beginning of the learning project, but that they adapted as they progressed according to their preferences, personal needs and according to random events, or 'organizing circumstances' as Spear and Mocker call them. Other similar results in Danis and Tremblay's study (1985) conflict with generally-accepted principles in the adult education field : the learners included in the study did not use a unique combination of learning methods that they thought was the best way to learn, but made use of a variety of learning modes and resources, turning from one to the other according to situations or learning events (432); to decide whether they had succeeded or not, these learners did not seek some kind of formal assessment, but considered the practical results they obtained or the inner feeling they had of having succeeded (430-431). 
The learning contexts in the studies led by Spear and Mocker and by Danis and Tremblay are very different from that of our university setting. However, we follow Little (1991) who sees learning autonomy 'as a psychological necessity’:

'For it appears that effective and worthwhile learning may actually depend on the extent to which learners achieve autonomy' (14).

Against the background of this thesis, learner autonomy being seen as fundamental to learning, we postulate that processes are similar in any type of learning, be it at home, at school or anywhere else. As one of the main lines of analysis in our doctoral research, we therefore set out to determine if and how students in our university language resource centres controlled or monitored their learning process. Very briefly, the three other lines of analysis retained were the following: to what extent learners explored the resources available in the LRCs; whether they developed learning routines; how they managed institutional constraints.

The corpus of data was then qualitatively analysed along the four main lines presented above. The procedure will be outlined here. One table was created per subject, showing all the data for the four working sessions, in order to apprehend observation data and interview data together. In the table, the different actions performed by the learner according to the observation report appeared in one column, while in the next column the quotations from the learner's discourse directly linked to each action were copy-pasted. In these tables, the researcher systematically identified all the parts of the observation data and interview data which she would consider for the four different lines of analysis: an item might therefore appear as an instance of exploration, control of the learning process by the learner, routine or constraint, or several of those. For practical purposes, four different colours were used in all tables, each corresponding to a line of analysis. The eight case studies were first analyzed as singular cases; then they were compared, in search of common and recurrent features, 
to try to come up with plausible hypotheses concerning the nature of processes involved in self-directed language learning in a university setting.

\section{Results and discussion}

The final results obtained for one line of analysis will be presented here and discussed.

The participants in the study were never paralyzed or lost: they always chose a resource and worked quite a lot with it. Most students appeared to spend very little time choosing resources, after exploring only a very small part of what was available in the centre (eg. reading the list of films in the resource catalogue; taking a brief look at available magazines on the shelves; spotting a pile of boardgames to choose from). When they chose to work with a resource, the learners rarely had a learning goal in mind: they did not often know or could not say why they had chosen to work with a certain resource, or if they had an aim, it was very general (e.g. learn more English vocabulary, understand spoken English better). They frequently indicated they had chosen this or that type of resource or resource because they liked it, which confirms the predominance of the emotional dimension in the learning process (Berthoz 2003; Damasio 1994; Candas and Eneau 2010). For instance, student Et10 liked playing a particular boardgame in French and therefore wanted to try playing in English; student Et6 loved this or that film. During the interviews and when the researcher insisted, some students justified some of their choices, using a cluster of more or less vague criteria having to do with what they thought of the linguistic value of the resource (because it was familiar or thanks to what teachers had said about it), what they knew about the process of learning a language, past learning experiences and more down-to-earth parameters such as what they felt like doing that day and how tired they were. However, it did not seem that these criteria had been rationally and 
consciously mobilized at the precise moment of the choice. It is only after having worked for quite a long period of time (eg. a whole work session) with a resource that some students said they had decided that they would go on with it or choose one of the same type: for example, student Et10, who, during her session, watched a cartoon in English which she had seen in French and almost knew by heart, stated in the interview that it was a more useful exercise to choose a video one knew well because of the work it had enabled her to do, comparing play-on-words in both languages. Unfortunately, the limited number of observation sessions did not enable us to confirm that these resources were then regularly made use of, except in one case study where student 9 used three times the same book and audio cassette on general scientific vocabulary because he felt it enabled him to progress as far as his listening skills and understanding of scientific vocabulary were concerned. In our data as in Danis and Tremblay's (1985), learners appear to assess the efficiency of a particular learning episode thanks to practical results or their inner feeling of having benefited from it.

In our study, we also analyzed how the participants proceeded with the chosen resources. For that, we distinguished two types of resources: traditional methods or lessons composed of a succession of standard exercises and resources where learners had more freedom to decide how to proceed. The first kind turned to be very interesting, particularly when several students worked with a similar resource. We will give one example with a dictation CD-Rom in which the learner's task is to transcribe an audio file verbatim, sentence after sentence, the software providing help by giving hints as to meaning and uncovering words at the learner's request. Student Et8 listened to every sentence a fixed and limited number of times, using hints but spending little time on them, before uncovering all the unheard words; she argued she 
did not want to spend too much time on each sentence. On the contrary, students Et9 and Et10 listened to each sentence an amazing number of times, before using a single hint and listening again numerous times, and uncovering one unheard word only after having tried everything else; they argued it was more beneficial that way. Student Et8 executed automatic actions without any reflection on the chosen method as far as learning is concerned, contrary to the two other students. For the second type of resources, the choice of the task or tasks by the learner revealed multiple influences, among which the exam modalities played a predominant role (students had to show a file with all their written productions to the teacher assessing their work), as well as teachers' general recommendations and past learning experiences at school which both placed high value on the same kinds of tasks (e.g. writing down news words and their translation, writing a summary). When asked why they were doing a summary of an article or a film, student Et5 answered that it meant she would have done something, while student Et4 first said it was for her, then corrected herself and admitted that she did not know, before finally talking about this task being a habit, something she always did (interestingly enough, in the next interview, she spontaneously told the researcher that she now thought she did summaries because they were an exam requirement). Institutional constraints and school routines seem to leave little room for more personal reflection and informed decisions, students being logically ready to do whatever is needed to pass their exams. Considering all the learning tasks chosen by the participants altogether, our data showed a very poor variety. However, our data also includes two clear instances where simply describing and explaining actions to the researcher induced learner reflection on a previous choice, leading the student to re-evaluate it in relation to an objective clarified out loud: for example, student Et6 systematically put English subtitles when watching 
videos, but, after being questioned during one of the interviews on this choice, ended up saying that, although she had not thought about it, it would be interesting to try another video without subtitles so as to train to better understand spoken English. We argue that, this finding, unexpectedly obtained thanks to the chosen methodology of the study, has important consequences for the nature of teacher support when wishing to promote the development process of learner autonomy: indeed, more than giving practical advice or encouraging and training learners to determine precise learning objectives and steps, it might be useful to act as the mirror of their actions and reflect back to them what they are doing and how they are proceeding and to enable them to talk about it, in the hope that explaining and justifying their choices might make them aware of incoherencies and envisage necessary changes. This interviewing technique of course reminds us of 'the counselling sessions' and its protagonist, 'the counsellor', whose role has been theorized by Gremmo (1995).

\section{Conclusion}

To sum up, what our analysis shows is that the learning paths of the participants in the study are structured by large and flexible goals (Danis and Tremblay 1985), or, more adequately, by a sort of 'fleeting intentionality', in which what one likes and how one feels also play a part, and by the resources readily available in the environment (Spear and Mocker 1984). We chose to refer to the way in which these learners control or monitor their learning process as 'loose piloting', where institutional constraints and habits or routines play a predominant role, rendering teacher support essential to trigger reflective thinking in learners and enable them to make more personal choices. The learners' focus is clearly on doing things and any inflection in the learning path or modes is decided upon as they progress, much more than things are planned from the beginning onwards. It must be said that 
the participants in the study admitted working mainly to validate their compulsory language credits, although all said they liked or found the English language useful, and that they did not report having a precise personal learning project as far as the English language was concerned. And of course one might argue that these eight learners are not autonomous at all. Our hypothesis, on the contrary, is that these students are autonomous learners at different degrees. Therefore, we argue that our study contradicts the widely-accepted assumption that planning (setting learning objectives, defining a programme and linear steps, choosing relevant learning methods and modes and assessing results in relation to pre-defined objectives) is central to self-directed learning. Although our results remain to be confirmed on larger numbers of learners studied for a longer time span, they open challenging areas of investigation into the nature of the processes involved in self-directed learning.

These results were obtained thanks to an original methodology, combining direct observation of the activity of individual learners during a series of work sessions in a language resource centre and subsequent directive interviews. Preliminary analyses showed that data resting solely on observation were not sufficient to formulate strong hypotheses on the nature of the processes taking place. Indeed, two students, apparently doing the same task on a similar resource, were in fact proceeding very differently. It is true that very fine observation of a series of actions when carrying out a task might enable the researcher to infer plausible hypotheses, but, to reach a conclusion, the students' answers in the interviews are needed. Our study also confirmed, after Vermersch (2003), that interviewees tended to discuss classes of events rather situated events, thus requiring that the interviewer firmly directs the interview. So, to have access to reliable data, observing effective work sessions is essential. To conclude, the exposed methodology, though complex 
and long to put into practice, can be deemed relevant for the study of the processes involved in self-directed learning in that it gives access to extensive and detailed information on these processes, which are not accessible by means of more traditional types of data collection.

\section{Acknowledgements}

I am deeply indebted to Jérôme Eneau, doctor in educational sciences and senior lecturer at The University of Rennes, France, for providing several major references without which my work would not have been what it is.

\section{Notes}

1) The Louis Pasteur University became part of The University of Strasbourg on January $1^{\text {st }} 2009$ when the three universities of Strasbourg (Marc Bloch University, Robert Schumann University and Louis Pasteur University) merged into a single university.

2) I am referring here to the version of the European Language Portfolio (ELP) which has been specifically designed for use in universities across Europe. It was accredited by the Council of Europe's Validation Committee at the request of CercleS (Confédération européenne des centres de langues de l'enseignement supérieur).

\section{Notes on contributor}

Peggy Candas, now doctor in educational sciences and a member of the LISEC (Laboratoire Interuniversitaire des Sciences de l'Education et de la Communication, The University of Strasbourg), defended her PhD at the University of Strasbourg in February 2009. She is also currently working in the language resource centres of the University of Strasbourg, as an English teacher and counsellor.

\section{References}

Albero, B. ed. 2003. Autoformation et enseignement supérieur. Paris: Hermès.

Astolfi, J.P. 2008. La Saveur des Savoirs: Disciplines et plaisir d'apprendre. Paris: ESF.

Benson, P. 2001. Teaching and Researching Autonomy in Language Learning. Harlow: Longman/Pearson Education.

Berthoz, A. 2003. La Décision. Paris: Odile Jacob.

Brookfield, S. 1981. Independent adult learning. Studies in Adult Education 13: 1527.

Brundage, D. and D. MacKeracher. 1980. Adult learning principles and their application to program planning. Toronto: Ontario Institute for Studies in education.

Candas, P. 2005. : Les usages des étudiants dans les centres de ressources de langues de l'Université Louis Pasteur: construction raisonnée d'un parcours ou itinéraire fortuit? Paper presented at the Troisième Colloque Mondial sur l'Autoformation ('Rencontres entre les cultures et les pratiques d'apprentissage formelles, informelles, non formelles'), November 23-25, in Marrakech, Morocco.

Candas, P., and J. Eneau. 2010. Autonomie de l'apprenant et dimensions affectives de l'autoformation. In Enjeux et dilemmes de l'autonomie. Une expérience 
d'autoformation à l'université. Étude de cas, ed. B. Albero and N. Poteaux. Paris: Les Éditions de la Fondation Maison des Sciences de l'Homme.

Carré, P. 1992. L'autoformation dans la formation professionnelle. Paris: La Documentation Française.

Carré, P. 2005. L'apprenance: Vers un nouveau rapport au savoir. Paris: Dunod.

Carré, P., and A. Moisan, eds. 2002. La formation autodirigée: Aspects psychologiques et pédagogiques. Paris: L'Harmattan.

Carré, P., A. Moisan, and D. Poisson. 1997. L'autoformation: Psychopédagogie, ingénierie, sociologie. Paris: Presses Universitaires de France.

Courtois, B., and H. Prévost, eds. 1998. Autonomie et formation au cours de la vie. Lyon: Chronique Sociale.

Damasio, A. 1994. Descartes' Error: Emotion, Reason, and the Humain Brain. New York: Avon Books.

Danis, C., and N.A. Tremblay. 1985. Principes d'apprentissage des adultes et autodidaxie. Revue des Sciences de l'Éducation 11, no. 3: 421-440.

Danis, C., and N.A. Tremblay. 1987. Propositions regarding autodidactic learning and their implications for teaching. Lifelong Learning 10, no. 7: 4-7.

Dumazedier, J. 2002. Penser l'autoformation: Société d'aujourd'hui et pratiques d'autoformation. Lyon: Chronique Sociale.

Eneau, J. 2000. Facteurs individuels et organisationnels d'influence de l'autoformation. Examen de synthèse de doctorat, Université de Montréal.

Fox, R.D. 1981. Current action principles and concepts from research and theory in adult learning and development. Paper presented at the meeting of the Society of Medical College Directors of Continuing Medical Education, Columbus, $\mathrm{OH}$.

Foucher, R., and M. Hrimech, eds. 2000. L'autoformation dans l'enseignement supérieur: Apports européens et nord-américains pour l'an 2000. Montréal: Éditions Nouvelles AMS.

Gibbons, M. et al. 1980. Toward a theory of self-directed learning: a study of experts without formal training. Journal of Humanistic Psychology 20, no. 2: 41-56.

Gremmo, M.-J. 1995. Conseiller n'est pas enseigner: le rôle du conseiller dans l'entretien de conseil. Mélanges Pédagogiques 22: 33-61.

Hiemstra, R. 1975. The older adult and learning. Lincoln: University of Nebraska.

Holec, H. 1981a. Autonomy and Foreign Language Learning. Oxford, NY: Pergamon Press.

Holec, H. 1981b. À propos de l'autonomie - Quelques éléments de réflexion. Études de Linguistique Appliquée 41: 7-23.

Holec, H. 1997. Main features of the educational approach adopted. In L'autonomie de l'apprenant en langues vivantes - Learner autonomy in modern languages, ed. H. Holec and I. Huttunen, 23-32. Strasbourg: Éditions du Conseil de l'Europe.

Knowles, M.S. 1971. The Modern Practice of Adult Education: Andragogy vs Pedagogy. New York: Association Press.

Leontiev, A. N. 1975. Activity, Consciousness, Personality. Moscow: Progress Editions.

Little, D. 1991. Learner Autonomy - 1 : Definitions, Issues and Problems. Dublin: Authentik.

O’Malley, J.M. and A.U. Chamot. 1990. Learning Strategies in Second Language Acquisition. Cambridge: Cambridge University Press. 
Oxford, R.L. 1990. Language Learning Strategies: what every Teacher should Know. Rowley: Newbury House.

Parsons, J. and T. Johnson. 1978. Adults learn differently than children: an examination of an old basic assumption. Kansas: Kansas State University.

Penland, P. 1979. Self-initiated learning. Adult Education Quarterly 29, no. 3: 170179.

Peters, J. and S. Gordon. 1974. Adult learning projects: a study of adult learning in urban and rural Tennessee. Knoxville: Tennessee Univ.

Poteaux, N. 2000. Nouveaux dispositifs, nouvelles dispositions. Les Langues Modernes 3: 8-11.

Poteaux, N. 2003. L'autoformation à l'université : de quelques éléments dialectiques. In Autoformation et enseignement supérieur, ed. B. Albero, 131-140. Paris: Hermès.

Pratt, D.D. 1984. Andragogical assumptions: some counter intuitive logic. Proceedings of the Twenty-Fifth Adult Education Research Conference: 147153. Raleigh, NC.

Spear, G., and D. Mocker. 1984. The organizing circumstance : environmental determinants in self-directed learning. Adult Education Quarterly 35, no. 1: 52-77.

Tough, A. 1971. The Adult's Learning Project: A Fresh Approach to Theory and Practice in Adult Learning. Toronto: Ontario Institute for Studies in Education.

Tremblay, N.A. 2003. L'autoformation: pour apprendre autrement. Montréal: Presses Universitaires de Montréal.

Tremblay, N.A., and J. Eneau. 2006. Sujet(s), société(s) et autoformation : regards croisés du Québec et de France. Éducation Permanente 3, no. 168: 75-88.

Vermersch, P. 2003. L'entretien d'explicitation. Issy-les-Moulineaux: ESF.

Wenden, A. 1983. Literature review: the process of intervention. Language Learning 33, no. 1: 103-121.

Zemke, R. and S. Zemke. 1981. 30 things we know for sure about adult learning. Training and Human Resource Development Journal: 45-52. 